\title{
The Changing Stereotypes of Librarian in Chinese Movies
}

\author{
Yuan Meng ${ }^{1}$, Yan Sun ${ }^{1 *}$, Rui Guan ${ }^{1}$, Dong Li $^{1} \&$ Zhonghong Zhang ${ }^{1}$ \\ ${ }^{1}$ Hubei University of Medicine, Wuhan, China \\ *Yuan Meng, E-mail: 351696411@qq.com
}

Received: March 17, 2017

doi:10.22158/wjssr.v4n2p108
Accepted: March 22, 2017

Online Published: April 13, 2017

URL: http://dx.doi.org/10.22158/wjssr.v4n2p108

\begin{abstract}
The representations of librarian in movies which is a main kind of media directly reflect and influence the audiences' opinions on this profession. This paper analyzed the changing stereotypes of librarian from several aspects by the method of context analysis, and found out that with the information era coming, there presentations of librarian in the movie is also generally changing. These findings can help librarians explore and rethink the self-marketing and self-shaping.
\end{abstract}

\section{Keywords}

librarian, stereotype, movies

\section{Introduction}

\subsection{Stereotypes}

Many theorists agree that stereotypes are characteristics that are descriptive of, attributed to, or associated with members of social group subcategories. Ashmore and DelBoca (1981) defined stereotypes as asset of beliefs about the personal attributes of a group of people. According to McCauley et al. (1980), stereotypes are those generalizations about a class of people that distinguish them from others. Stereotyped as are created during the perception process when the observer forms fixed and over simplified ideas or images of a particular group or class of people (ScottandMarshall, 2005), and these images are of tenant real and biased (Colman, 2001).

Stereotypes can be found that are associated with nations, ethnic groups, social classes, religions and professions. Stereotypes can be positive, negative or mixed, and are applied indiscriminately to all members of a group, without allowing for individual differences. Although stereotypes contain some truth, these are often generalized and biased, and yet are accepted as a "reality". Understanding of stereotypes is important because people treat members of other groups based on their stereotyped views (Swim et al., 1989) and interact, at least initially, with the stereotype rather than with the true person. This results in many individual injustices, since only some persons in the group fully fit the stereotype. 


\subsection{The Stereotypes of Librarian}

Walker and Lawson (1993) studied Hollywood movies in which librarian roles were contained and founded "Amid the thousands of films produced by Hollywood, librarians appear in a small number". Furthermore, they pointed the librarian in movies are frequently female and are likely to be introverted, unmarried, prim and shy. According to Ann Seidl, director of the documentary The Hollywood Librarian, librarians in film are often portrayed as meek, timid and unassertive in nature.

Raish lists about 550 Hollywood (and a few foreign) productions that in some significant or memorable way include a library or librarian. In this list, librarians were portrayed as being over forty, wearing old fashion glasses, cloth, hair-styles. They were always hushing others and gave others the impression of weird and conservative.

Compared with the Hollywood movies, librarian roles were showed less and shorter in Chinese movie and teleplays. The systematic researches on this topic were also less. Jianlin $\mathrm{Xu}$ analyzed the representing details of librarian roles of six Chinese films, and found most of these roles are introverted, strict, serious, having service consciousness. Lijing Li also pointed the female librarians in Chinese moive and teleplays have always been shaped as weak, sacrificial and being dominated.

These images which represented by films and teleplays influence the public's thinking about the image of librarians, "Family Feud" game show a group of 100 people were surveyed and asked what they believed to be typical "librarian" characteristics. The top 5 characteristics disclosed showed that librarians were:

1) Quiet;

2) Mean or Stern;

3) Single/Unmarried;

4) Stuffy;

5) In Glasses (Kirkendall, 1986, pp. 40-42).

\section{Method}

Matin Raish has divided the data films into four groups as A, B, C, D which is respectively Someone says or does something that clearly identifies himself or herself (or some other character) as a librarian, librarian or library as settings, librarian was only mentioned, someone is listed in the credits as "librarian". In the study, seven Chinese movies and four teleplays as Group A from 1990s to 2010s were chosen as the research data. Content analysis was used to research what Chinese librarians in media like and whether they were changed with time changing from the aspect of gender, age, appearance, personality, job duty and tools. 


\section{Librarian Stereotypes in Chinese Screen}

\subsection{Gender and Age}

Fifteen of the twenty-three librarians (65 percent) portrayed in screen were female. While this is not necessarily a negative portrayal, it does reinforce the general stereotype that librarianship is a feminized profession. Although there are men to join the librarian profession, females still have the predominance in the profession. It is also further evidence for Biyang Yu's perspective that in public awareness, the profession of librarian has significant feminine features in China.

The age characteristic was difficult to determine since the exact age of the librarian was rarely evident. From the descriptions of the characters, it can be inferred that the majority of the librarians were between age twenty-five to forty. Different from the perception of "The old maid librarian is perhaps the most common stereotype of librarians found in the mass media". The librarian portrayed for decades in Chinese screen were more like middle-aged or young. The Qing Chen in Zhou Yu's Train, Wen in Time Lapse, Xi Xu in Black Mask, Xinxin in Pandora's Booth, Xingyu Ye in The Foliage, are all unmarried young librarian. And Yaqin in DancingWill Be Better, Qingniao in Marriage Work, Qiao Lin in Agreed Not To Separate, Xiaoxue in Hand In Hand, Xiaofeng in Chinese Style Divorce, Shaolong Lin in The Blue Kite, were all middle aged people who are just married or raising little child. It proves the age stereotype has began to be shattered by featuring younger librarian characters in Chinese screen.

\subsection{Appearance}

Although some librarians were described as young and attractive, according to Black, their appearance also always indicates repression in some way.

According to Kress and Van Leeuwen (2006), "color clearly can be used to denote people, places and things as well as classes of people, places and things, and more general ideas. The colors of flags, for instance, denote states, and corporations increasingly use specific colors or color schemes to denote their unique identities". It also can "merge with the ideational metafuction, but it is also about an attempt to act upon others, to have an effect upon them" (Machin, 2007, p. 66).

Machin (2007) also pointed that bright color can be usually associated with happiness and dark with sadness. Besides these, light and bright color might be also associated with relaxation, peace, softness, vigorousness, etc. Dark color might be usually associated with steadiness, solemnity, ration and calmness. The majority of librarians in the movies and teleplays wore black and white, rare of them were in bright colors. Only three of twenty-three librarians (13\%) were wearing red or other bright color cloth when they were working. Xi Xu in Black Mask wore a black old fashioned Chinese tunic suit from the beginning to the end. The three librarians showed in Agreed Not To Separate, Yaqin in Dancing Will Be Better, Wen in Time Passing were all wearing black or white work suit with sleevelets. This kind of using colors indicates the features of librarian are earnest, simplicity, reserved. In the aspect of costume and hair style, they were all very simplicity with no fashion accessories such 
like necklace or ear-rings. Female librarians images, just like former research, were rolling up their hairs and combing a bun when they were working, which indicates the features of oppression and boredom.

Furthermore, the study found there is great contrast between the librarians' dressing, colors, hair styles in working status and daily status. For example, Qingniao in Marriage Work, is a young female who has just got married. She was portrayed as a librarian in a university. She was fashionable in daily life, wore clothes with various bright color, vogue ear-rings and hairs down which made her seem vivacious. In the contrast, she portrayed as only wore black and gray suits with bun in hair when she was working. Same as Qingniao, Qiao Lin in Agreed Not to Separate was also shaped as that wore work suit with bun at work and change bright color clothes with hair down off work.

The finding support that although films or teleplays still prefer to use elements such as conservative, serious, low-key to shape librarians and librarianship, they have already had more various appearances in the screen. Such as vivacious and fashionable instead of only conservative in former.

\subsection{Personality}

Slight changes of the personality of librarian characters have been found by analyzing the samples which are from 1990s to 2010s.

At 1990s, majority of the librarian image were negative. The librarian in Hard Boiled (1992) is a supporting role who witnessed a shooting case. When the case happens, she stood behind the bookshelf and did not dare to shout for help. She also can't provide any useful information when polices ask. The image of her is discouraged and dull. In The Black Mask (1996), Xi Xu use being librarian to cover his real identity of killer. He was introverted, gentle, honest, cold when he was as a librarian and all his librarian colleagues in his eyes were "like talking gossip", "obsess in love". Xiaoxue in Hand In Hand (1998) was portrayed as a librarian who sacrifice herself for the family. She was coward, endurable, dependent, low self-conscious. After her husband had an affair, what she only can do was begging her husband to stay. Qiao Lin in Agreed Not To Separate (1999) had been suffered by the truth that her husband was not her son's birth father and eventually chose to divorce. Her personality is sensitive, dependent, poor in communication, can only escape when things happen. The librarians in four 1990s movies and teleplays, their images are all negative and difficult to get audiences' acceptance.

Things were getting better after 2000s. More and more positive librarian images appeared in screen. In The Foliage (2003), Xingyu Ye was a well educated youth worked in a school library. When the curator blamed her because of the broken of a sculpture, she tried to explain but unable to speak due to the tense, just use smile to face the curator. Although the image of her was not good at communication, but was still gentle, polite, dignified. One of other librarian in this film was also represented as decent and enthusiastic. In Time Lapse (2003), the cheif librarian uncle Qi was a warm, kind, lovely, erudite old man. The protagonist when is a young librarian graduated from Peking University with master degree. He was elegant, sedate and busy in work all day. Xinxin in Pandora's Booth (2009) is a assistant 
librarian. She would come forward to speak to the boy she likes and would adopt the stray dogs. She was open, enthusiasm, kind, good-hearted. Given the samples, five librarian in seven were portrayed as positive images. In addition, their personality were shaped as more and more outgoing and extroverted. In recent years films or teleplays, like Dancing Will Be Better (2010), the librarian Yaqin was not only elegant, polite in working, but also fashionable and positive in daily life. She never gave up the expectation for true love and confidently showed herself on TV. Qingniao in Marriage Work (2012) was a independent, vigorous, beautiful, typical "after 80s" young woman. She pursued for freedom, had her own opinions and wasn't willing to take the arrangements from parents. Both of the images prove that librarians were represented not only tend to have positive personality, but also follow the trend in recent years. They are barely portrayed as old-fashioned people.

All these findings support that some images of librarian in medias have changed generally as well especially on personalities. It indicates with the world has entered an information era, the function of librarianship became more and more important, and although the librarians stereotype is still exist, the public cognition of librarians has already began to change.

\subsection{Job Duties and Tools Used}

In this category a definite change in tools over time could be seen. In early movies, typewriters, print encyclopedias, and circulation cards were used, while in most recent movies computers were revealed as the dominant reference tool. This indicates that librarian has been generally typified as a kind profession with high technology which must possess state-of-the-art work skills to do. This fact implies that intelligence and education are required for these tasks.

But what opposite is these changes were showed up in the aspect of job duties of librarian. Although computer existed as the dominant tool, librarians' job duties which were represented in those Chinese movies were still borrowing books, shelving books. Their abilities and duties of consulting, information retrieval, information processing had never been represented. Furthermore, some of lines and behaviors in those movies also indicate the stereotype of librarians' nature and duties of work. In The Black Mask (1996), Xi Xu said when he introduce his own job, "there are lots of books can read, but often no one comes". In Hand In Hand (1998), librarians had portrayed as bending over the desk to sleep, making phone calls to chat, eating snacks, reading newspapers when they were working and always came to work late and left early. In Dancing Will Be Better (2010), there was no staff in the counter when reader came to pay the overdue fine and librarians came late with still eating their breakfast. All these conveys the conception of this profession is leisure, undisciplined which was largely discrepant with the truth.

\section{Conclusion}

Overall, the librarians in Chinese movies were no longer portrayed as negative, quiet, mean, stuffy any more as before. Their representations in screen became more and more positive in information era. 
Although they still tended to be portrayed in old fashion, dark color clothes, there are some general changes on their image especially on their personality and tools used. Their images became more elegant, knowledgeable, vivacious and so on. The librarians' job responsibilities, also had few changes as no longer simple as before, more high-technological. But leisure, undisciplined stereotypes of librarians are still exist in screen.

Changes in perception require time and a concerted effort on the part of the stereotyped population to change popular opinion about who they are and what their role is in society. It need mass media continue change the existing librarians stereotypes from the aspects of both external image and internal knowledge literacy. What is more it need librarians to market themselves through the way such as PR activities, media promotion, various communication to shape good social image and get public understanding and acceptance step by step.

\section{Acknowledgement}

Supported by Library and Information Committee for Academic libraries of Hubei Province (Grant No.2015YB02).

\section{References}

Black, S. (1993). Checking Out the Librarian: The Depiction of Librarians and Libraries on Prime Time Television. Popular Culture in Libraries, 4(1993), 35-62.

Kress, G., \& Van Leeuwen, T. (2006). Reading Images: The Grammar of Visual. Routledge.

Li, L. J. (2010). Female librarians images in media. News Dissemination, 2010(2).

Machin, D. (2007). Introduction to Multimodal Analysis. London Arnold.

Raish, M. (1998). Librarians in the Movies. Library Mosaics, 9(4), 12-15.

Seale, M. (2009). Old Maids, Policeman, and Social Rejects: Mass Media Representations and Public Perceptions of Librarians. Electronic Journal of Academic \& Special Librarianship, 9(1).

Seidl, A. (2012). The Hollywood librarian, 33(3).

Walker, S., \& Lawson. (1993). The Librarian Stereotype and the Movies, 1993(1), 16-28.

Xu, J. L. (2011). Analysis and reflection of images of librarians in Chinese movie and TV works. Library Development, 2011(2), 107-110. 